\title{
Relationship between Teacher Professional Performance and Discipline of Workers with Teacher Professionalism in Madrasah Tsanawiyah in Pematangsiantar City
}

\author{
$\underline{\text { Kalsum Saragih }}{ }^{1}$, Mardianto $^{2}$ \\ ${ }^{1}$ Master Student in Islamic Education Management, FITK, UIN-SU, Indonesia \\ ${ }^{2}$ Lecturer in Islamic Education Management, FITK, UIN-SU, Indonesia \\ Email: kalsumsaragih71@gmail.com
}

\begin{abstract}
This study aims to determine: 1) the relationship between professional money teachers with professional teachers in MTs Pematangsiantar, 2) the relationship between the discipline of working with the professionalism of teachers in MTs Pematangsiantar, and 3) the relationship between the Advantages of the teaching profession and discipline of cooperation with the professionalism of teachers in MTs Pematangsiantar. This research is a quantitative research with correlation research type. This study was conducted in 9 (nine) MTs Pematangsiantar is MTs Negeri, MTsS MESRA, MTsS Khoirotul Islamiyah, MTsS Guppi, MTsS Madani Al Islamiya School, MTsS Ibnu Sina, MTsS Fathul Islamiyah, MTsS YPI, MTsS Al Khairiyah. The population was 88 people and the sample size of the study was 72 people. The results showed; 1) there is a positive and significant relationship between vocational teachers of professionalism of the teacher, if the value of the correlation coefficient is 0.439. 2) There is a positive and significant relationship between the discipline of working with the professionalism of the teacher when the correlation coefficient is 0.502, and 3) a positive and significant relationship between professional money and discipline with the professionalism of teachers with a correlation coefficient of 0.561.

Keywords: teacher occupation support; work discipline; teacher professionalism
\end{abstract}

\section{Introduction}

Someone who is said to be professional is if he has the ability and attitude in accordance with the demands of his profession. Although the government has tried to improve the professionalism of teachers, but has not produced the competencies as expected.

Some teachers at various levels and educational units are not suitable to teach, because they do not have sufficient competence to become a professional teacher. For this reason, the government continues to implement various coaching steps so that teachers are fit to teach. One way that the government has taken is to conduct a teacher certification program. In this way the teacher is expected to become a professional teacher, especially in the sense of being worthy of teaching. One of the ways taken by the government is the teacher certification program (Simon Sili Sabon, 2017). Also we can see in the field that there are teachers who have not used varied learning strategies that seem boring to students. There are still many teachers who do not master the content and subject matter taught as well as insights related to the subject matter they teach.

One factor that influences teacher professionalism is work discipline. Work discipline is the ability of one's work to continuously work in accordance with applicable rules and does not violate existing regulations. The work discipline in question is the work discipline of the teacher, the work discipline of the teacher is the orderly and orderly attitude that the teacher has in working at school without violations (Rissa Poppy Azizah et al, 2016).

Teacher professionalism is a necessity that cannot be delayed anymore, along with the increasingly intense competition in the era of globalization, in accordance with its capacity to be 
able to play a maximum role, including teachers as a profession that requires its own skills and expertise. Professionalism is not only due to the demands of the times, but basically it is also a necessity for every individual in the framework of improving the quality of human life. Professionalism requires the seriousness of adequate competence, so that someone is considered worthy to carry out a task.

According to the analysis of researchers to reach the level of "professional teacher" is so many stages that must be done. And the core of the teaching and learning process is the teacher, and so many designations for the teacher that is the teacher as a facilitator, the teacher as a motivator, the teacher as a motivator and the teacher as an inspiration and the teacher as a professional also has a legal basis.

Based on observations in the field, the teacher's presence is still not in accordance with expectations, including: 1) discipline of attendance both to school and in the classroom. 2) Often leave the class and leave the class ahead of the end of the lesson. 3) Less sensitive and do not care about changes in the world of education. 4) be indifferent and do not like to guide students. 5) Don't want to increase ability. 6) Explain the task only to a minimum extent. 7) Satisfied only by doing their daily routine and others.

\section{Review of Literature}

Professionalism comes from the word profession which means a field of work that someone wants or pursues. A profession is a position or occupation that demands certain expertise. This means that professional positions cannot be carried out or held by any person who is not trained and is not specifically prepared for the field he is in. For example, a professional teacher who has teacher competence through teacher education such as (S1 PGSD, S1 Education, AKTA Education) obtained from special education for the field. (Rusman, 2012: 18).

In addition, professional teachers are required to have three abilities, firstly cognitive abilities, meaning teachers must have mastery of the material, methods, media, and be able to plan and develop their learning activities. Second, psychomotor abilities, means that teachers are required to have knowledge and ability to implement the knowledge they have in their daily lives. Third, affective ability, means the teacher has a noble character, maintained behavior, so that he will be able to become a model that can be emulated by students (Suyanto and Djihad, 2013: 8).

With the professionalism of the teacher, the future teacher no longer appears as a teacher (teacher), such as its prominent function so far, but instead as a coach (coach), a guide (counselor) and a learning manager (learning manager). Meanwhile the attitudes and qualities of a good teacher are 1) being fair 2) trusting and liking the students 3) patient and willing to sacrifice 4) cheerful 5) being good towards other teachers 6) being good towards the community 7) being good towards community 8) really mastered subjects 9) likes the subjects they provide and 10) knowledgeable (Kunandar, 2006: 51).

In principle, professional teachers are teachers who can carry out their duties professionally, which have characteristics including:

\section{a. Expert in Teaching Theory and Practice.}

Professional teachers are teachers who master the science taught and experts teach it (convey it). In other words, professional teachers are teachers who are able to learn their students about the knowledge they master well. 


\section{b. Pleased to Enter the Teaching Profession Organization.}

A job is said to be a professional position one of the conditions is that the job has an organization and its members are happy to enter the organization. Teachers as professional positions should have an organization. The function of professional organizations in addition to protecting the interests of its members is also as a dynamic and motivator member to achieve a better career (Kartadinata, in Meter, 2000)

\section{c. Have an Enough Teacher Education Background.}

Teacher's expertise in carrying out educational tasks is obtained after taking certain teacher education that is not possessed by other professions. There are several roles teachers can play as educators, including: (a) As a professional worker with the function of teaching, guiding and training. (b) Humanitarian workers with the function can realize all their human capabilities. (c) As a benefit officer with the function of teaching and educating the public to be good citizens.

\section{d. Implement the Teacher Code of Ethics}

In the national education convention 1 of 1988, that the profession is a job that has a code of ethics that is certain norms as a guideline or guidelines that are recognized and respected by the community.

\section{e. Have Autonomy and Sense of Responsibility}

Teachers must have an independent attitude in carrying out their duties. The independence of a teacher can be characterized by having the ability to make value choices, can determine and make their own decisions and account for the decisions they choose.

\section{f. Have a passion to devote themselves to the community.}

Teachers as educators are at the heart of educating the community's life. For this reason, teachers are required to have high devotion to the community, especially in teaching students.

\section{g. Working on a Heart Call}

In carrying out the duty of community service should be based on encouragement and calling of conscience. So that the desert will feel happy in carrying out the daunting task of educating students (Ade Cahyana, 2006)

Madrasa teachers who are entitled to a professional allowance are determined through a decision on the authority to use the budget (KPA) in the work unit of the Ministry of Religion in the district / city and / or state madrasas. The amount of the madrasah professional allowance is as follows:

- Government employees teachers are given an allowance of the basic salary per month.

- Non-Government employees teachers who have been equaled (in passed) are given an allowance of 1 (one) time base salary per month adjusted by taking into account the rank, position and academic qualifications that apply to PNS teachers as stated in the SK In passing, do not take into account the provisions of tenure according with the provisions of the legislation.

- Non-Government employees teachers who have not been equaled (non-in passed) are given a professional allowance of Rp. 1,500,000 (one million and five hundred thousand rupiah) per month in accordance with the legislation Professional allowance of one month of basic salary received for government teachers (PNS) and non-permanent 
teachers (not PNS) of Rp 1,500,000 ( one million five hundred thousand rupiahs) per month after fulfilling the requirements in accordance with applicable laws and regulations, and subject to income tax in accordance with tax provisions (Technical Guidelines and Dirjen 2018)

Discipline is an attitude of willingness and willingness to obey and obey the norms of regulations that apply in the surroundings. Good employee discipline will speed up company goals, while declining discipline will become a barrier and slow down company goals. Discipline shows a condition or attitude of respect that exists in employees against the rules and regulations of the company. Thus if the rules or regulations in the company are ignored, or often violated, then the employee has poor discipline. Conversely, if employees are subject to company regulations, illustrate the existence of good conditions of discipline

\section{Research Method}

Research on the relationship between teacher professional allowance and work discipline with teacher professionalism in Madrasah Tsanawiyah Pematangsiantar City, conducted on teachers in 9 (Nine) Madrasah Tsanawiyah Pematangsiantar City (MTsN, MTsS MESRA, MTsS Khoirotul Islamiyah, MTsS GUPPI, MTsS Madani Al Islamiyah School, MTsN, MTsS MESRA, MTsS Khoirotul Islamiyah, MTsS GUPPI, MTsS Madani Al Islamiyah School, MTsS MTsS Ibnu Sina, MTsS Fathul Islamiyah, MTsS YPI, MTsS Al Khairiyah).

This research is categorized as correlational research (Correlational Research), to find out (measure) the relationship between two or more variables. The sample in this study were 72 teachers in Madrasah Tsanawiyah, Pematangsiantar City. This research variable consists of two independent variables and one dependent variable. The independent variable consists of teacher professional allowance variables and work discipline while the dependent variable is teacher professionalism. The data collection method used in this study was a questionnaire. Data analysis techniques use simple linear regression analysis techniques (simple regression) and multiple linear regression (multiple regression).

\section{Discussion}

Table 1. Teacher Professional Allowance Regression Results $\left(\mathrm{X}_{1}\right)$ with Teacher Professionalism (Y)

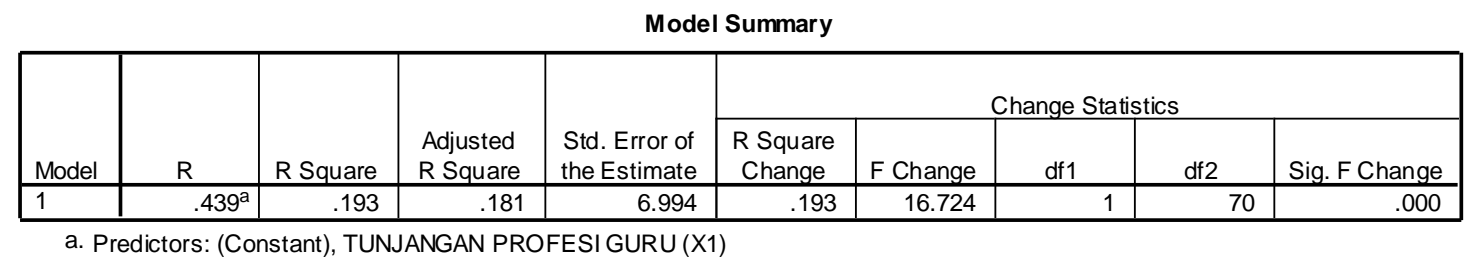

From the table above it is known that the results of simple linear regression calculations show an $\mathrm{R}$ value of 0.439 , indicating that the value of the relationship that occurs between the independent variables of professional teacher allowance $\left(\mathrm{X}_{1}\right)$ with the dependent variable of teacher professionalism $(\mathrm{Y})$. R square value of 0.193 or $19.3 \%$ states that the value of the strength of the relationship that occurs between the two variables. This means, the better the teacher professional allowance will be followed the better the professionalism of teachers in madrasas. This statement is corroborated from the value of $\mathrm{R}$ Square $19.3 \%$. 
Table 2. Work Discipline Regression Results $\left(\mathrm{X}_{2}\right)$ with Teacher Professionalism (Y)

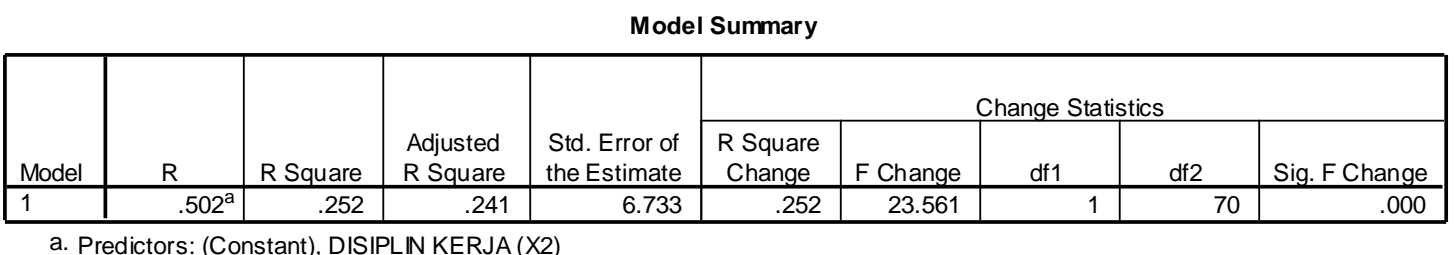

From the table above it is known that the results of simple linear regression calculations show an $\mathrm{R}$ value of 0.502 indicating that the value of the relationship that occurs between the independent variables of work discipline $\left(\mathrm{X}_{2}\right)$ with the dependent variable of teacher professionalism $(\mathrm{Y})$. R square value of 0.252 or $25.2 \%$ states that the value of the strength of the relationship that occurs between the two variables. This means, the better the work discipline is followed the better the professionalism of teachers in madrasas. This statement is corroborated from the value of $\mathrm{R}$ Square $25.2 \%$.

Tabel 3. Multiple Regression Results between Teacher Professional Allowance (X1) and Work Discipline $\left(\mathrm{X}_{2}\right)$ with Teacher Professionalism $(\mathrm{Y})$

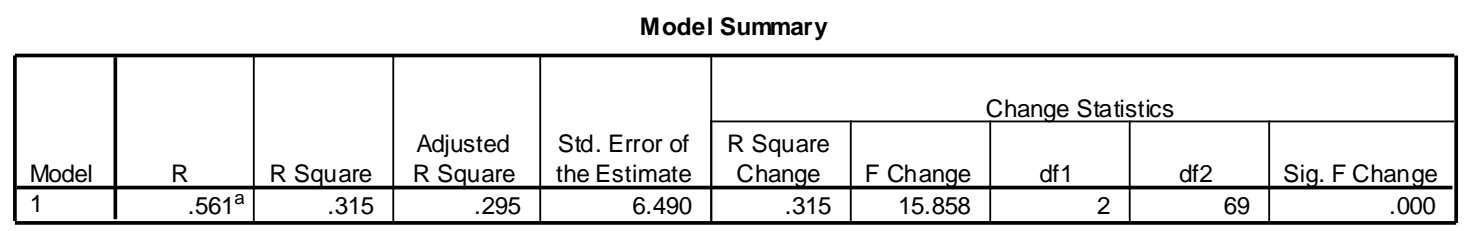

a. Predictors: (Constant), DISIPLIN KERJA (X2), TUNJANGAN PROFESI GURU (X1)

From the table above it is known that the results of the multiple linear regression calculation can be seen the value of $\mathrm{R}$ together at 0.561 shows that the value of the relationship that occurs between the independent variable teacher professional allowance (X1) and work discipline (X2) together with the dependent variable of teacher professionalism ( Y). R square value of 0.315 or $31.5 \%$ stated the value of the strength of the relationship. This means that the better the professional allowance for teachers and work discipline followed by the better professionalism of teachers in madrasas. This statement is corroborated from the value of $\mathrm{R}$ Square $31.5 \%$.

The relationship between the two variables in this study is 0.439 . This means that the relationship that occurs in the two variables is positive, so that if the teacher professional allowance variable gets better the better the teacher professionalism variable in madrasas.

While the value of $\mathrm{R}$ square is 0.193 or $19.3 \%$ which states the value of the strength of the relationship owned by the two variables. This means, the better the teacher professional allowance, the better the professionalism of teachers in madrasas. Thus, the relationship that occurs between the teacher professional allowances variable (X1) and teacher professionalism (Y) is a moderate correlation (strong correlation) with the strength of the relationship only $19.3 \%$.

From the results of statistical calculations on the teacher professional allowance variable includes the last diploma, competence (pedagogical, professional, personality, social), and educator certificates in Madrasah Tsanawiyah Pematangsiantar included in the excellent category of 0 respondents, good category totaling 51 respondents, adequate categories good as many as 13 respondents, and categories not as good as 8 respondents. From this table it can be concluded that the level of propensity for teacher professional allowance variables (X1) is at a good level $(71 \%)$. This means that the professional allowance for teachers is in the good category of application. Then when connected with teacher professionalism which includes attitudes towards 
legislation, attitudes toward professional organizations, attitudes towards peers, attitudes towards students, attitudes toward work, attitudes toward leaders, and attitudes towards work included in the excellent category of 1 respondent, both as many as 42 respondents, in the good enough category as many as 24 respondents, and the bad category as many as 6 respondents This means that the professionalism of teachers is in the good category (58\%) in its application.

Thus it can be concluded that the relationship between teacher professional allowance (X1) and teacher professionalism (Y) in Madrasah Tsanawiyah Pematangsiantar is in moderate correlation with a value of 0.439 and the strength of the relationship between the two variables is 0.193 or $19.3 \%$. This is in accordance with research conducted by Wardi Syafmen that there is an impact of certification on the professionalism of work for teachers in Jambi City Junior High Schools is quite positive. Teachers who have received professional allowances are able to set aside a budget to improve their professionalism such as buying a laptop, attending seminars, workshops, buying supporting books, buying books and learning powerpoints. All that are done with full self-awareness of the importance of improving the quality of self after receiving professional allowance.

The relationship between the two variables in this study is 0.502 . This means that the relationship that occurs in the two variables is positive, so that if the discipline variable works well, the better the teacher professionalism variable in the madrasa.

While the value of $\mathrm{R}$ square is 0.252 or $25.2 \%$ which states the value of the relationship strength of the two variables. This means that the better the discipline of work the better the professionalism of teachers in madrasas. Thus, the relationship that occurs between the works disciplines variable (X2) and teacher professionalism (Y) is a moderate correlation (strong correlation) with the strength of the relationship $25.2 \%$.

From the results of statistical calculations on work discipline variables including complying with work guidelines, obeying rules at school, sanctions for teachers who are late attending school, and sanctions for teachers who do not collect administrative tasks of teachers in Madrasah Tsanawiyah Pematangsiantar included in the very good category only 1 respondent. Respondents who answered about work discipline (X2) included in the good category by 39 respondents, in the good enough category by 27 respondents, and the bad category by 5 respondents. From this table it can be concluded that the tendency level of work discipline variables (X2) is at a good level (54\%). This means that work discipline is in the good category in its application. Then when connected with teacher professionalism which includes attitudes towards legislation, attitudes toward professional organizations, attitudes towards peers, attitudes towards students, attitudes toward work, attitudes toward leaders, and attitudes towards work included in the excellent category of 1 respondent, both as many as 42 respondents, in the good enough category as many as 24 respondents, and the bad category as many as 6 respondents This means that the professionalism of teachers is in the good category (58\%) in its application.

Thus, it can be concluded that the relationship of work discipline (X2) with teacher professionalism $(\mathrm{Y})$ in Madrasah Tsanawiyah Pematangsiantar is in moderate correlation with a value of 0.502 and the strength of the relationship between the two variables is 0.252 or $25.2 \%$.

This is consistent with Bister Panjaitan's research that there is an influence of work discipline on teacher professionalism in Vocational High School 2 triple "J" and this underlies his behavior, moral principles, social and intelligent decisions on what is right and good to do. Thus the patterns of attitude and disciplinary action of the teacher will be able to create a more 
effective and productive learning process, so as to stimulate the many ways that will be able to enrich the teaching process that is the best and most effective.

The relationship that occurs between the teacher professional allowance variable (X1) and work discipline (X2) together with the teacher professionalism variable $(\mathrm{Y})$ is a relationship that has a moderate correlation (strong correlation). This can be seen from the correlation coefficient between the two variables, 0.561 .

While the value of $\mathrm{R}$ square is 0.315 or $31.5 \%$ which states the value of the relationship strength of the two variables. This means, the better the teacher professional allowance and work discipline, the better the teacher's professionalism in madrasas. Thus, the relationship that occurs between the teacher professional allowance variable (X1) and work discipline (X2) with teacher professionalism $(\mathrm{Y})$ is a moderate correlation (strong correlation) with the strength of the relationship only $31.5 \%$.

From the results of statistical calculations on the teacher professional allowance variable includes the last diploma, competence (pedagogical, professional, personality, social), and educator certificates in Madrasah Tsanawiyah Pematangsiantar included in the excellent category of 0 respondents, good category totaling 51 respondents, adequate categories good as many as 13 respondents, and categories not as good as 8 respondents. From this table it can be concluded that the level of propensity for teacher professional allowance variables (X1) is at a good level (71\%). This means that the professional allowance for teachers is in the good category in its application. In the work discipline variables which include adhering to work guidelines, obeying rules at school, sanctions for teachers who are late attending school, and sanctions for teachers who do not collect administrative tasks in the Madrasah Tsanawiyah Pematangsiantar included in the very good category only 1 respondent. Respondents who answered about work discipline (X2) included in the good category by 39 respondents, in the good enough category by 27 respondents, and the bad category by 5 respondents. From this table it can be concluded that the tendency level of work discipline variables (X2) is at a good level (54\%). Then if the two variables are associated with teacher professionalism which includes attitudes towards legislation, attitudes toward professional organizations, attitudes toward peers, attitudes towards students, attitudes toward work, attitudes toward leaders, and attitudes towards work are included in the excellent category as many as 1 respondent, both 42 respondents, in the good enough category as many as 24 respondents, and the bad category as many as 6 respondents This means that the professionalism of teachers is in the good category (58\%) in its application.

Thus it can be concluded that the relationship between teacher professional allowance (X1) and work discipline (X2) together with teacher professionalism (Y) in Madrasah Tsanawiyah Pematangsiantar is in moderate correlation with a value of 0.561 and the value of the strength of the relationship between the two variables is equal to 0.315 or $31.5 \%$.

\section{Conclusion}

Based on the results of the hypothesis test that has been described previously, it can be concluded several things as follows: first, there is a positive and significant relationship between teacher professional allowance (X1) with teacher professionalism (Y) in Madrasah Tsanawiyah Pematangsiantar with a moderate level of correlation (strong correlation), with a correlation coefficient of 0.439 . Relationship between two variables stated positive, if the value of a variable is increased, it will increase the other variables and vice versa if a variable is lowered then it will decrease the other variables. The relationship between these two variables is 0.439 . This means 
that the relationship that occurs in the two variables is positive, so that if the teacher professional allowance variable is getting better, it will be good for teacher professionalism in madrasas. While the value of the strength of the relationship that occurs between the two variables amounted to 0.193 or $19.3 \%$ which states the value of the relationship strength possessed by these two variables means that the better the professional allowance of the teacher, the better the professionalism of teachers in madrasas. Thus the relationship that occurs between the teacher professional allowance variable with teacher professionalism is a moderate correlation (strong correlation).

Second, there is a positive and significant relationship between work discipline (X2) and teacher professionalism $(\mathrm{Y})$ in Madrasah Tsanawiyah, Pematangsiantar city with a moderate correlation level (strong correlation), with a correlation coefficient value of 0.502 . This means that the relationship that occurs in the two variables is positive so that if the work discipline variable is good, the better the teacher professionalism variable will be. While the value of the strength of the relationship that occurs between the two variables is 0.252 or $25.2 \%$. This means that the better the work discipline, the better the professionalism of the teacher. Thus the relationship that occurs between the variables of work discipline with teacher professionalism is a moderate correlation (strong correlation).

Third, there is a positive and significant relationship between teacher professional allowance $\left(\mathrm{X}_{1}\right)$ and work discipline $\left(\mathrm{X}_{2}\right)$ with teacher professionalism $(\mathrm{Y})$ in Madrasah Tsanawiyah, Pematangsiantar city with moderate correlation level (strong correlation) with correlation coefficient value of 0.561 . While the value of the strength of the relationship that occurs between the two variables is 0.315 or $31.5 \%$. Both of these independent variables go hand in hand with the dependent variable, meaning that the better the teacher professional allowance and work discipline, the better the teacher's professionalism.

\section{References}

Cahyana Ade. Pengembangan Kompetensi Profesional Guru Dalam Menghadapi Sertifikasi, Pusat Statistik Pendidikan, Balitbang Kemendiknas.

Djihad Asep and Suyanto. (2013). Menjadi Calon Guru dan Guru Profesional. Yogyakarta: Multi Pressindo.

Kunandar. (2006). Guru Profesional. Jakarta: Rajawali Press

Musfah Jejen. (2011). Peningkatan Kompetensi Guru. Jakarta: Prenadamedia Group.

Panjaitan Bister, Pengarub Insentif, Sertifikasi Guru, dan Disiplin Kerja Terbadap Kinerja Guru, Jurnal Manajemen Jasa, Vol 3 N0.2 2016

Prabu, Mangkunegara. (2015). Daya Manusia Perusahaan. Bandung: Remaja Rosdakarya.

Poppy Rissa Azizah. (2013). Pengaruh Pengawasan, Kompensasi, dan Disiplin Kerja Terhadap Kinerja Pada Guru Sertifikasi, Jurnal

Rusman. (2012). Model-model Pembelajaran. Jakarta: PT Raja Grapindo

Sabon Sill Simon. Persepsi Siswa Terbadap Kompetensi Guru Yang Sudab dan Belum Sertifikasi, Jurnal Pusat Penelitian Kebijakan, Balitbang Kemendikbud. 